\title{
6. Threatened Lives
}

\author{
Afghan Protests against Deportations, Berlin, 2016-2017
}

\begin{abstract}
"[T] he readmission agreement between Afghanistan and the German government - it's a shame! Everyday people get killed there - innocent people, children, women, men, every day. [...] It disgusts me. When I'm thinking about it I'm full of anger, full of anger."
\end{abstract}

\begin{abstract}
The decision by the German government in 2016 to resume summary deportations to Afghanistan sparked a series of protests in which thousands of Afghans, mostly asylum seekers with a precarious legal status, organized marches, sit-ins and petitions in the German capital. This chapter traces the interactive dynamics leading to temporary mass protests despite contexts of marginalization of a group which has previously mostly abstained from contentious action. The chapter documents the role of Afghan diaspora and migrant support groups in Berlin in providing spaces of encounter and trust building. In these spaces, and in the context of an existential threat for precarious migrants at risk of deportation, a deeply ingrained fear and internal cleavages within the Afghan exile community could be temporarily overcome.
\end{abstract}

Keywords: migrant protest; deportations; threats; interactions; Afghanistan; Berlin

The summer of 2015 marked important changes in the salience and politicization of migration in Germany (Grande 2018). While the country witnessed the emergence of an unprecedented citizens' mobilization in support of migrants (Hamann and Karakayali 2017) and liberal turns in

Steinhilper, E., Migrant Protest: Interactive Dynamics in Precarious Mobilizations. Amsterdam: Amsterdam University Press 2021 DOI: 10.5117/9789463722223_CHo6 
Chancellor Merkel's position on refugees (Laubenthal 2019), the "long summer of migration" was also followed by a series of asylum law restrictions and an increasingly hostile public debate (Rea et al. 2019). Afghans, one of the largest groups of asylum seekers in Germany, have been particularly affected by this turning tide (Fischer 2019). In October 2015, government officials declared the goal to reduce asylum applications from Afghanistan and introduced a series of restrictions. In autumn 2016, this culminated in the decision to resume summary deportations to the conflict-ridden country (Bundesinnenministerium 2016).

The readmission agreement between the German and Afghan governments sparked a series of protests, in which thousands of Afghans, mostly asylum seekers with a precarious legal status, organized marches, sit-ins and petitions in the German capital. This chapter traces the interactive dynamics leading to temporary mass protests despite contexts of marginalization of a group, which has previously mostly abstained from contentious action. ${ }^{2}$ It documents the role of Afghan diaspora and migrant support groups in Berlin in providing spaces of encounter and trust building. In these spaces, and in the context of an existential threat for precarious migrants at risk of deportation, a deeply ingrained fear and internal cleavages within the Afghan exile community could be temporarily overcome. The protest trajectory furthermore illustrates how actors shift from strategic "silence" to "voice" (and back) in precarious mobilizations.

\section{Politicizing Differentiated Treatment}

Despite objective indicators of prosecution and systematic violence in Afghanistan, ${ }^{3}$ in the second half of 2015 , top government officials accentuated a discursive and practical distinction between a small group of "welcome refugees" and those collectively deemed unwanted. In

2 This chapter focuses on Berlin, yet, protests against deportations to Afghanistan were not limited to Berlin. Large-scale demonstrations were also organized in Frankfurt (Handelsblatt 2017), Munich (Kaminski 2017) and Hamburg (Hamburger Abendblatt 2017). Yet, they were mainly rooted in local communities rather than tied together in a national network.

3 These are mirrored in corrected protection rates of $68 \%$ in 2014 and $79 \%$ in 2015 , respectively (author's calculations based on BAMF data (BAMF 2015, 2016). In contrast to the uncorrected number, the corrected protection rate counts only those cases that have been decided materially, hence deduces from the total number of decisions all those that have been rejected on formal grounds, e.g., for the reason of a Dublin transfer. This corrected number more accurately captures the risk of prosecution and violence in a respective country of origin (Mediendienst Integration 2018). 
October 2015, the Asylpaket I (Asylum Package I) law entered into force. This entailed a liberal move granting asylum seekers from countries with a "good perspective to remain"4 access to "integration courses" with a strong language course component (Lochner 2018; Laubenthal 2019). While five countries fell into this criterion - Syria, Eritrea, Somalia, Iraq and Iran - it collectively excluded Afghans, although they constituted one of the largest asylum-seeking communities, given their uncorrected recognition rate of just below the threshold in 2015 (BAMF 2016). Less than a week later, the public opposition against Afghan migrants was made explicit. On October 28, then Minister of Interior Thomas de Maizière declared the high number of asylum applications from Afghanistan to be "unacceptable" noting that "the Afghan youth and the middle-class families should remain in Afghanistan and rebuild their country" (Die Bundesregierung 2015, author's translation). This discursive turn foreshadowed targeted policy restrictions on migration from Afghanistan. In December 2015, Chancellor Merkel publicly warned Afghans from migrating to Europe, underlining that "a hope for better life is no reason to be granted asylum or a right to stay in Germany," and offered the Afghan government money and logistics to prevent departures (Zeit Online 2015, author's translation). In an overall context in which political conflicts over migration to Germany multiplied, the Merkel government continued a process of increasing differentiation of precarious migrants in Germany. Therefore, Afghans became the most prominent example of "second class asylum seekers" (Ruttig 2017). A second major asylum law restriction in early 2016 (Asylpaket II) further aggravated the situation for Afghans, as it entailed the two-year suspension of family reunification for individuals with a subsidiary protection status (Pichl 2016). This hit the Afghan community particularly hard. Despite an unabated continuation of conflicts with a record number of civilian casualties in the Central Asian country (UN OHCHR 2016), the rejection rates of asylum seekers from Afghanistan increased drastically from $22.3 \%$ in 2015 to $39.4 \%$ in 2016 (BAMF 2017, 2016b). ${ }^{5}$ However, as the objective danger for civilians in Afghanistan remained high, less generous protection status such as subsidiary protection or protection on humanitarian grounds proliferated among Afghans (BAMF 2017). Also in 2016, advocates for further asylum

4 This criterion is operationalized by a protection rate of above $50 \%$ for individuals of the respective country in the previous year.

5 The office in charge (BAMF) justified rejections by pointing at the possibility to internally relocate Afghans to areas less affected by violence (Pro Asyl 2018). 
law restrictions mobilized acts of violence perpetrated by asylum seekers and other migrants. Thus, highly mediatized felonies by young Afghans further spurred an increasingly widespread position to collectively limit the arrival of asylum seekers from Afghanistan and their presence in Germany (Ruttig 2017; Fischer 2019).

In this general climate, the German government intensified the negotiations with their Afghan counterparts. Following up on previously negotiated financial benefits in exchange for controlling emigration, a focus was now put on readmission agreements for deportations (Reuters 2016). In October 2016, both the German government and the EU signed agreements with the Afghan government (EEAS 2016; Bundesinnenministerium 2016), with "the objective to establish a rapid, effective and manageable process for a smooth, dignified and orderly return of Afghan nationals who do not fulfil the conditions in force for entry to, presence in, or residence on the territory of the EU" (EEAS 2016). ${ }^{6}$ According to public sources (Deutscher Bundestag 2016), more than 12,000 Afghans with a rejected asylum claim were at immediate risk of being deported, and potentially thousands more with a pending asylum case, considering the decreasing recognition rates (Gerner 2016). In December 2016, for the first time in twelve years, Germany resumed summary deportation flights to Afghanistan (ARD Tagesschau 2016).

\section{Protest Emergence: A Mobilized Diaspora}

This rapid shift for Afghans did not remain unnoticed by the Afghan exile community in Berlin. While the overall perception of a German "welcome culture" prevailed (Laubenthal 2019), Afghans continuously accumulated countless experiences of their differentiated treatment, and the negative repercussions it had on their lives. A young Afghan who arrived in 2015 in Germany together with his family, recalled the concrete effects of these discursive and policy changes: "My wife is from Iran, I am Afghan. We went to the language school, and they said, 'Your wife can come to the integration course. She is more than welcome. But you cannot.' I was shocked. Why?" (Interview B41).

Yet, at the beginning, the Afghan diaspora community intended to deal with the situation with noncontentious means. Those in an ongoing asylum procedure felt the discrimination, but chose to remain silent, considering this be the best strategy to obtain a right to stay. Those parts of the more 
established Afghan community who were willing to engage in the support of their compatriots with a precarious legal status joined in to the proliferating movement of asylum seekers support in Germany. Given their skills but also due to their knowledge of the complicate situation for Afghans, they tailored their services to the specific needs of Afghans, offering language courses and translation and legal advice during the asylum process (Interviews $\left.\mathrm{B}_{3} 8, \mathrm{~B} 40\right)$. However, they increasingly realized that their engagement was futile and unable to balance the proliferating discursive and administrative restrictions. The frustration turned into indignation, when they learned about the governmental goal to prepare the legal ground for summary deportations to a war-torn country. One of them, a young Afghan journalist, expressed a widespread sentiment: "We Afghan refugees are discriminated against in Germany. Compared to Syrian refugees, for instance. No doubt, the situation in Syria is horrendous. But in Afghanistan, we experience a war for 40 years. [...] Afghanistan is extremely insecure but nevertheless we are not welcome" (Interview B36).7

The signature of the readmission agreements constituted a crucial turning point, since it posed an existential threat for asylum seekers and a source of fundamental indignation for all those familiar with the security situation in conflict-ridden Afghanistan: "Within less than one year, the 'welcome culture' has been transformed for Afghans into a deportation culture" (Interview B35). This external event triggered a politicization of various individuals and groups, which engaged in organizing the heterogeneous Afghan community to actively converge, and to create a contentious compound player powerful enough to be listened to. Up to this point, the Berlin-based Afghan diaspora had remained fragmented along the lines of religion, ethnicity, language and ideology. As a result of a four-decade-long conflict in Afghanistan, with shifting power constellations, distinct parts of the Afghan society were forced to leave the country. These divisions and memories of oppression have been kept alive in exile, which was why Afghans have rarely mobilized based on a collective national identity, in Berlin (Romeo 2001; Daxner and Nicola 2017). ${ }^{8}$

The decision by the German government to resume summary deportations to Afghanistan constituted a "moral shock" (Jasper 2014) among parts of the Afghan exile community. While Afghans with a pending asylum

7 Similar expressions were used in Interviews B37, B39.

8 In previous episodes of precarious migrant protest in Germany, Afghans had also not played a major role despite their numerical size (Jakob 2016). 
case were immediately affected by the successive restrictions and, it was particularly a diverse group of more established Afghans in exile who were rapidly politicized. No matter if they had previously organized language courses, cultural festivities or sports for Afghans, all of a sudden they became involved in a fight for a right to remain (Interviews B37, B38, B40): "We had already been involved in direct support - language courses, legal advice, translation, and the like. Our explicit political work started after the agreement between the German and Afghan government. [...] We couldn't believe it; [...] that anyone could be so presumptuous to deport people to Afghanistan. We were shocked" (Interview B38).

While a pending asylum case or a temporary suspension from deportation (Duldung) had been a source of uncertainty and worry for many Afghans even before, the possibility of large-scale deportations planted an existential threat for all asylum seekers with a precarious legal status. Despite the fact that those initiating the mobilization were the "lucky ones" with a right to stay, they had developed a sense of responsibility vis-à-vis their compatriots under an increasing threat of deportation: "I managed to leave the asylum facility and get a right to stay. But it is not about myself. Having gone through this and knowing what it means urges me to assist my fellow compatriots now" (Interview B39).

Given their own biography of forced displacement, those Afghans who had already obtained a secure status not only empathized with the panic felt by those who had not but were also outraged by the German government denying a reality of insecurity. One of them, an Afghan TV journalist who had herself escaped from Kabul to Germany after a thwarted acid attack in 2014, noted: "The readmission agreement between Afghanistan and the German government - it's a shame, everyday people get killed - innocent people, children, women, men, every day. [...] It disgusts me. When I'm thinking about it, I'm full of anger, full of anger" (Interview B39).

Precisely because they were familiar with the precarious and demobilizing effects of an ongoing asylum procedure or even more so, with the anxiety related to a risk of imminent deportation, the organizers felt they had to play a central role in the mobilization. Initially fragmented in various groups with limited or no interaction, associations run by Afghans or Germans of Afghan descent (such as Yaar e.V., Itehad e.V., Newsgroup Afghanistan, Afghanisches Kommunikations- und Kulturzentrum e.V. ${ }^{9}$ and Hazara World Council) and also individuals, realized that they had to join forces against what they considered an outrageous injustice (Gürgen 2017; 
Weissenborn 2016). Despite their diversity in terms of age, ethnicity, religiosity, permanence in Germany, and experience of activism, the readmission agreement brought up a common cause. Interactions multiplied to open spaces for exchange, and strategizing. From summer 2016 onward, when information of a readmission agreement first spread, and even more so after its signing, associations and individuals started to get in touch with Afghans living in the asylum facilities to make it clear: "In case you want to stay in Germany, you have to become active. We have to raise awareness for our problems and the situation in Afghanistan. If you stay silent, you will have no chance" (Interview B43).

The spark of protest was set, but it needed to be incubated and find resonance in the large population of directly affected Afghans with a precarious legal status. Simultaneous to increased networking within the Afghan diaspora in Berlin, exchanges also intensified with larger migrant support associations, such as Flüchtlingsrat Berlin, ${ }^{10} \mathrm{BBZ}$ Berlin, ${ }^{11}$ $\mathrm{KuB},{ }^{12}$ and Verein Iranischer Flüchtlinge, ${ }^{13}$ which were already in contact with Afghans in their counseling sessions, as well. These associations with a long tradition of precarious migrant support were surprised by this unprecedented interaction with a range of diaspora groups and the involvement of individuals with an influential role in the various Afghan communities. This novel set of actors eventually joined forces and founded a new compound player, the Berlin Alliance against Deportations to Afghanistan (Interviews B35, B36, B38). Before this collective actor mobilized thousands to the streets of Berlin and became visible as a public player, an intense process of organizing was necessary. Networks were knit and spaces were created to cut through the deeply engrained emotion of fear and to temporarily bridge the internal cleavages within the Afghan exile population. The core aim was to act as and be recognized as a compound political and contentious player.

Given their familiarity with the demobilizing effects of the asylum process and particularly the accommodation in collective facilities in remote areas, the core set of initial protest organizers, were aware of the need to reach out to the precarious Afghan population and built trust. The main challenge

10 Refugee Council Berlin.

11 Beratungs und Betreuunszentrum für junge Geflüchtete und Migrant*innen, a center for the counseling and support of young refugees and migrants in Berlin.

12 Kontakt- und Beratungsstelle für Flüchtlinge und Migrant_innen (Contact and Counseling Office for Refugees and Migrants).

13 Association of Iranian Refugees. 
was to gradually cut through a deeply rooted fear and intuition to remain silent instead of speaking out:

The first step for every refugee [in the German asylum system] is to live in a first reception center. It is the first institution where you learn basic information about Germany. And what do they do there? They silence you. From the very beginning, everyone urges you: If you want to stay in Germany, be silent, be a good refugee, integrate into society. Plus, they isolate you physically. You are far away and surrounded by fences. They separate you from the rest of society as if they wanted to deny your existence. (Interview B39)

From their own experience and through exchanges in counseling, they knew the widespread state of fear and disillusion among the asylum seekers (Schleiermacher 2017; Starzmann 2017). Instead of protesting against exclusion, in these contexts of marginalization, many individuals become apathetic and gradually lose their sense of agency (Täubig 2009; Pieper 2008). When rumors spread in the asylum facilities that Germany will resume deportations to Afghanistan, the omnipresent fear (Starzmann 2017) and uncertainty became an existential threat. One of the Afghan organizers, who has been granted subsidiary protection but continued living in an emergency shelter, recalled:

Since Germany deports, all Afghans are terrified. Everyone who does not have a residence permit is constantly afraid. I personally witnessed the situation when a young Afghan jumped out of the second floor of the asylum facility, when he saw a police car parking in front of the building. They did not come for him, but he was panicking. (Interview B43)

This constant anxiety had intensified, since the German government started to allow deportations without prior notice in October 2015 (Pichl 2016). From then on, rejected asylum seekers had to expect a deportation at any time, day or night. Given this internalization of fear, when organizers started reaching out to Afghans with a precarious legal status and proposed organizing a protest, they encountered reluctance. Despite sharing a sense of injustice and anxiety about a potential deportation, the strategy of confronting the state was considered counterproductive. Due to the dependence on the state in obtaining the right to stay, many initially opted for "silence" instead of "voice": "At the beginning, many Afghans were afraid to attend demonstrations. They said: if we go to a protest, perhaps the German politicians 
and administrators will see this and we will get our cases rejected or even deported. We will stay at home instead and try to stay as silent and invisible as possible" (Interview B43).

The fact that many of the core organizers were Afghan, or Germans with a personal migration history from Afghanistan, facilitated outreach, as information could be shared and doubts be discussed in the main Afghan languages, Dari and Pashtu. On the other hand, the deep cleavages within the Afghan exile community also posed, at times, additional obstacles that had to be overcome. Some asylum seekers in the collective accommodation facilities were immediately suspicious when an Afghan broker from a distinct ethnicity than their own got in touch to inform them and offer spaces of encounter and strategizing (Interview $\mathrm{B}_{3} 8$ ).

In this climate, the diverse activities offered by Afghan community associations, but also other migrant support organizations working with Afghans, became the spaces for encounter, mutual trust building, empowerment and politicization. Itehad e.V., the first Afghan soccer club, originally founded to provide moments of relief from a burdensome life in exile, became a space to discuss possibilities to counter the turning tide against Afghan asylum seekers (Weissenborn 2016; Interview B37). Newsgroup Afghanistan organized platforms for young Afghans to meet and exchange views (Borkowsky 2019; Interview B45). The magazine KulturTür by and for persons with a history of forced displacement brought together individuals to share stories of their life in exile, which also included stories of exclusion and resistance (Interviews B36, B45). ${ }^{14}$ Yaar e.V. and Afghanisches Kommunikations- und Kulturzentrum served as "bridges of communication between Afghan refugees and other Berliners" (Rezaie 2018a, author's translation). These associations both facilitated the convergence of different actors within the Afghan population in Berlin and brokered ties to larger migrant support organizations, such as Verein Iranischer Flüchtlinge, BBZ, and Flüchtlingsrat Berlin, which also contributed to (self-)organization with the provision of rooms and expertise. These social spaces organized by and for migrants, which were often not political in their original purpose, became spaces of empowerment and encounter for a previously fragmented and politically demobilized Afghan exile community in Berlin.

While these spaces of encounter were initially almost exclusively created by individuals with a secure legal status, asylum seekers with pending cases soon became actively involved as well. They played an important role, since they served as additional and credible relays to precarious migrants, who 
still considered "silence" an effective strategy to achieve a right to stay. One of the young Afghans who became an active organizer serves as an illustration of the interactive dynamics, which contributed to the incubation of precarious protests in Berlin: In summer 2016, he was still anxiously waiting for the decision on his asylum case. Accommodated in the city's largest emergency shelter, Berlin Tempelhof Airport, ${ }^{15}$ with thousands of other asylum seekers, he heard about an Afghan cultural event and hoped for a moment of relief (Interview B45). At the event, Newsgroup Afghanistan had set up "Afghan Memory," a space in which Afghans could share their stories from a life before exile. The contacts he made there, and the feeling of empowerment prompted him to stay engaged and become a member of the group himself, even after his asylum claim got rejected and the risk of deportation grew:

I was afraid at the beginning, too. If I go to the demo, if I show my face publicly, on television, this would be bad for my asylum case. [...] But then I thought, "Germany is a free country and a democracy," and I realized, if you are afraid and stay at home, they can do whatever they want with you. I knew a lot of people, talked with others in our [newsgroup about politics. [...] If I am afraid, the others are afraid, too, I thought I have to do something to give energy to others to do the same. (Interview B45)

During regular interactions with other Afghans at various events organized by different diaspora groups, he realized that patience and silence was the wrong strategy in light of an imminent threat: "If I do not fight, they will send me back. [...] I have to fight for my life" (Interview B45). When the first summary deportation flights were scheduled, the Berlin Alliance against Deportations to Afghanistan announced a demonstration. While established migrant rights organizations formed a part of the alliance and contributed with their resources and expertise, the news about a protest of Afghans was also diffused in the newly created networks of the Afghan exile community. Calls for protest in Dari and Pashtu rapidly circulated in Afghan social media groups, during cultural and sports events, and as leaflets in collective asylum facilities (Interview B36). The spaces of encounter created before had produced decentralized messengers within

15 Berlin Tempelhof Airport (which had ceased operating as an airport in 2008) temporarily hosted thousands of asylum seekers in highly precarious conditions (Berliner Morgenpost 2015). 
the precarious migrant community: "By the time I still lived in "the hangar. ${ }^{16}$ I knew a lot of people there and in other facilities. When a demonstration was planned, I called all my contacts and posted it on Facebook to let the [Afghan] people know" (Interview B45).

\section{Protest Incubation: From "Silence" to "Voice"}

The call for action for the first demonstration of the Berlin Alliance documented the combination of an existential threat inducing constant emotional stress and the indignation to be deported to a country with one of the most fragile security situation worldwide: "We demand [...] the immediate EU-wide halt of deportations to Afghanistan; the immediate stop of psycho terror by both the media and public institutions with their constant threat of deportation to human beings who have been on the run from war and terror for almost four decades" (cited in KuB 2016, author's translation).

On protest day, 10 December 2016, days before the first summary deportation to Afghanistan was executed (ARD Tagesschau 2016), 1,500 demonstrators marched to Brandenburg Gate in central Berlin, despite freezing temperatures (Die Welt Online 2016). As an emblematic case of transnational migrant activism (Steinhilper 2018), the protesters carried signs with slogans such as "Afghanistan is not safe" and "We are human beings, not numbers," but also photographs of human rights abuses in the Central Asian country, articulating claims against the German government and the insecurity in Afghanistan. In contrast to other promigrant or antiracist demonstrations in Berlin, German protesters remained a minority. It was mostly the Afghan community itself that took to the streets, and among them, many at immediate risk of deportation (Ehrich 2016). They expressed:

What will happen in case I am deported? It is obvious. Today, three hours ago, in the Afghan province of Helmand in the city of Lashkar Gah, fourteen persons were killed and eight injured. In case we get deported, what will happen? Thousands of young Afghans died in 2015 and 2016 in suicide attacks. The same will happen to all of us. (Newsgroup Afghanistan 2017, author's translation)

The desperate situation and an existential threat to their lives, mobilized a community, which had long hoped to be granted a right to stay by silent 
"integration." Among the protesters were many young males with a particularly high risk of deportation and many members of the ethnic group of the Hazara, ${ }^{17}$ who faced particular risks upon return:

If they decide I have to go back to Afghanistan, they sign my death sentence, because I am Hazara. The so-called Islamic State and the Taliban said that they do not care if we have the same religion or culture. If you are Hazara, they will kill you. Perhaps it will take one or two months, or maybe a year or two. But if I return to Afghanistan, I will die. (Newsgroup Afghanistan 2017, author's translation)

Aware of the precarious conditions of asylum seekers and their unlikely attendance at demonstrations, the Berlin Alliance organizers had expected a larger turnout of Germans acting in solidarity, yet the Afghan participation exceeded their hopes (Interview $\mathrm{B}_{3} 8$ ). The combination of an existential threat, as well as their efforts to provide spaces of empowerment and access to resources, had contributed in overcoming the odds of mobilization in contexts of marginalization.

The first demonstration was just the kickoff for a series of protest events. In February 2017, the Berlin Alliance again mobilized more than thousand people to the streets (Berliner Morgenpost 2017). Also in this second protest event, the majority of the participants were Afghans, again, many with a precarious legal status (Newsgroup Afghanistan 2017; Berliner Morgenpost 2017). Using the momentum of the first two demonstrations with large turnouts, regular protests followed, targeting the various actors involved in the precarious situation of Afghans. These included the German refugee agency (BAMF) and its practice of increasingly issuing rejections on asylum claims by Afghans (BBgAA 2017b), the Ministry of the Interior (Hillebrand 2017), the Afghan embassy for its cooperation in the readmission agreement (BBgAA 2017C; Schleiermacher 2017) and the office of the state of Bavaria in Berlin, from where the first summary deportations to Afghanistan were effectuated (BBgAA 2017a). The Berlin Alliance invented the hashtag \#Bleibistan, ${ }^{18}$ launched a large Twitter campaign and joined in broader campaigns for migrant rights in Germany (Interviews B36, B45, B38). Picketing took place when terrorist attacks occurred in Afghanistan in order to draw attention to the argument that Afghanistan was anything but safe and German

17 The Hazara are an ethnic minority in Afghanistan, which has experienced discrimination and violence for decades (Fischer 2019).

18 A German wordplay fusing the terms "bleiben" (remain) and Afghanistan. 
politicians claiming the opposite were hiding the truth (Rasuoli and Yaghobi 2017): "We escaped from war, from lies and incompetent power holders in Afghanistan. Now we are exposed to the lies of some German politicians" (Rasuoli and Yaghobi 2017, author's translation). Previously absent from the contentious arena around asylum and migration in Berlin, the series of protests and its supporting networks introduced Afghans as a visible compound player and connected it to the resources of larger migrant rights organizations in the German capital.

The case of protests against deportations to Afghanistan thereby echoes previous research on patterns of activism in contexts of marginalization. Firstly, it documents the ambivalent effect of fear on political mobilization. While on the one hand, fear tends to discourage protest, it can have the opposite effect once it is perceived as a collective threat, to which a collective response is needed (Zepeda-Millán 2014). Secondly, precarious mobilizations are often organized around a few influential personalities with organizational and linguistic skills and experiences in activism (Nicholls and Uitermark 2016) serving as brokers to these disenfranchised communities. Also in undocumented migrant protest, associations and groups without an explicit political agenda, such as sports and cultural clubs, have obtained a crucial function in resource mobilization and trust building in times of threats.

\section{Dynamics of Demobilization}

Despite the continuation of protest activity of the Berlin Alliance throughout the summer and autumn of 2017, also including a long-term picket with a hundred participants, directly before the German national elections in September (BZ Online 2017), the visibility and size of protests decreased markedly, and abruptly, three months after the first demonstration. This was the reaction to the shifting position of another player: in response to public pressure to which the protests contributed and internal debates, the centerleft regional government of Berlin, which had only shortly before the protests taken office, declared on 22 February 2017 to temporarily suspend summary deportations to Afghanistan with the exception of convicted criminals and individuals labeled as "potentially dangerous terrorist offenders"19 (Die Welt Online 2017). Even though other German states continued with the summary deportations of Afghans, this public statement reduced the 
imminent threat for precarious migrants in Berlin. The relieving news rapidly spread within the same networks, which had previously led to the large turnouts during demonstrations. Participation in subsequent protests visibly dropped:

[W] hen the Afghan migrants were relatively sure that they will not be deported [...] many did not participate in the subsequent protest activities with the same urgency. For instance, when we organized a demonstration in front of the Representation of the State of Bavaria ${ }^{20}$ in Berlin after a deportation flight of Afghans from Munich, many fewer people showed up. (Interview B38)

As soon as the acute threat of imminent deportation decreased, three dynamics set in. Firstly, many Afghans drew their attention toward addressing other pressing questions of a life in exile. Since a suspension of deportation reduced the imminent threat, but did not solve the hardships of a life with the nonstatus of Duldung: "[W]e would get more attention if our fellow Afghans would not rest on the highly fragile and temporary commitment that Berlin does not deport 'ordinary' Afghans. But they have tons of other problems and often still internalize the position: the more discrete we are, the more merciful the German society will act toward us" (Interview B38).

Accordingly, with a decreasing threat, many precarious migrants shifted back to a repertoire of silent inclusion, which they considered more effective to address their urgent needs like finding a housing alternative to the precarious emergency shelters, getting access to language courses, and finding a job to sustain their families (Interview B35). Considering the alternatives, many opted against a long-term sociopolitical engagement and for finding individual solutions to their immediate problems.

Secondly, after a moment of resistance without alternatives, many Afghans were drawn back again into a state of apathy, typical for a life in legal limbo. One of those precarious migrants who stayed engaged referred to his Afghan roommate to underline this demobilizing dynamic:

I have a roommate. He is Afghan, too. We both got our asylum claims rejected. When I try to motivate him to get engaged, he says, "No, I will not do anything until I get a right to stay. I cannot. Even when I go to school, I forget everything. I think too much about what will happen if I get rejected again." (Interview B45) 
And lastly, with the fading threat, the fragile unity of a highly heterogeneous player with multiple internal cleavages collapsed. The alliances built during mobilization were strong enough during an exceptional time, yet, soon, the old conflicts and divides became dominant, and distinct players within the diverse Afghan community pursued distinct and often opposite interests:

The division and distrust resulting from 40 years of interethnic and religious violence is also present within the Afghan exile community. In Berlin, the debates between religious and secular Afghans have been going on for decades. The religious faction obviously has an interest in advocating for a conservative lifestyle. [...] It is easy to discredit the protest movement from a conservative perspective. They argue, for instance, that if you go to a demonstration, there will be homosexuals there, and people fighting for women's rights, and this is not in line with the religious values. (Interview $\mathrm{B}_{3} 8$ )

The temporary success in bridging between various religious and ethnic groups, was replaced again by prevailing distrust and reluctance: one of the organizers noted with disillusioned realism that "the Afghan community [did not] exit" (Interview B37) but consisted of competing subplayers: "[People] argued increasingly, this association is religious, this one is not, they are more 'Afghan' than these, this group only caters to this ethnic group. [...] This fragmentation, which has always existed, is now an obstacle to sustainable mobilization" (Interview B38).

Despite the dynamics of visible demobilization in terms of numbers, the core of Afghan individuals and associations, who had converged for the first time in preparation of the protest, remained connected afterward. They had also gained new members willing to keep the recently emerged contentious Afghan diaspora "in abeyance" (Taylor and Crossley 2013); to be prepared to organize mass protest in case of a resumption of deportations to Afghanistan from Berlin. Aware that a united Afghan voice would be necessary to move beyond the protest against deportations and press for inclusive policies in Germany, they continue, against all the odds: "Personally, I don't agree with most of them [Afghan refugees]. I'm not a Muslim; I am an atheist and a Marxist. Yet, we are all human beings" (Interview B39). "We continue working on bridging these divides. But perhaps we need to wait one generation, until the bruises of 40 years of conflict start to heal" (field notes, 12 December 2018). 


\section{Conclusion}

The interactive dynamics unfolding during the series of protests against deportations to Afghanistan between 2016 and 2017 in Berlin carve out two key aspects of precarious migrant mobilizations: the mobilizing effect of threats, and the important role of mobilized diasporas. Firstly, the chapter underlines that threats, rather than opportunities, are crucial for understanding protest dynamics in contexts of marginalization (Zepeda-Millán 2017). Confronted with various challenges of a life without secure legal status, the strategy of protest is chosen in moments of existential hardship. Whereas in most situations of precariousness, individuals concentrate on getting by through silent adaptation. The decision by the German government to resume deportations to the conflict-ridden country posed such an existential threat among precarious migrants from Afghanistan. Individuals and groups in regular contact with Afghan asylum seekers, from both the diaspora and migrant support groups, immediately sensed the seeds of panic the readmission agreement had planted. This confrontation with anxiety, but also with their own familiarity with the context of violence in Afghanistan, sparked deep indignation among a small set of Afghans and Germans with a biography of forced displacement from Afghanistan. A "moral shock" prompted them to take action and work on the convergence of an exile community, strongly divided along the lines of ethnicity, religion and ideology. Those asylum seekers directly at risk of deportation first tended to react with a strategy of silent adaptation, and they hoped invisibility rather than "voice" would allow them to stay in Germany. In this ambiguous context, individuals and groups from the Afghan diaspora played a crucial role in the dynamics of mobilization. Through repeated encounters in settings, which did not have a political purpose, such as sports and cultural events, they facilitated both an empowerment of disenfranchised individuals, and they built a temporary bridge between different factions of the Afghan diaspora. The combination of an existential threat and a space provided by the more established Afghans and migrant support associations allowed the creation of a large compound player with an Afghan identity. It eventually encouraged thousands of precarious migrants to overcome their fear and take the streets.

Besides these dynamics of protest emergence and incubation through interaction, the case study also documents the fragile unity in precarious activism, which complicates long-term mobilization. The convergence into a collective compound player, as well as large turnouts for demonstrations, were strongly dependent on the perception of an acute and direct threat for 
the persons involved. When the regional government in Berlin declared a de facto deportation ban, many Afghans shifted back to "silence," invisibly trying to cope with the multiple challenges of a life in continuous uncertainty. When the uniting threat decreased, the internal fragmentation of the Afghan exile community resurfaced and decomposed the compound player into ethnic, religious, and ideological factions, with competing individual and group interests.

Notwithstanding this demobilization, for the first time, both individual Afghans and exile associations have knit dense networks within and among migrant support groups in Berlin, which might be remobilized in case the threat of deportation intensifies. Indeed, the temporary suspension of deportations from Berlin could be revoked at any time, since the removal of rejected asylum seekers has remained a core priority for high-ranking politicians and many regional governments have continued with forced returns after the regional suspension of deportations to Afghanistan from Berlin. Minster of the Interior Horst Seehofer $\left(\mathrm{CSU}^{21}\right)$ proudly announced in summer 2018: "Coincidentally, on my $69^{\text {th }}$ birthday, 69 persons have been deported to Afghanistan" (Spiegel Online 2018). One of the deportees committed suicide right upon arrival in Kabul (Zeit Online 2018), underlining the severity of the grievances on which Afghans had engaged in acts of resistance, against all the odds.

\section{References}

ARD Tagesschau. 2016. "Rückkehr in eine unsichere Zukunft." 15 December. https:// www.tagesschau.de/inland/abschiebungen-afghanistan-105.html.

BAMF. 2015. "Das Bundesamt in Zahlen 2014." Nürnberg.

—. 2016. "Das Bundesamt in Zahlen 2015." Nürnberg.

—. 2017. "Das Bundesamt in Zahlen 2016." Nürnberg.

BBgAA. 2017a. "Aufruf zur Demonstration am 22.02.2017." Berliner Bündnis gegen Abschiebungen nach Afghanistan.

—. 2017b. "Aufruf zur Demonstration am 27.03.2017." Berliner Bündnis gegen Abschiebungen nach Afghanistan.

—. 2017c. "Aufruf zur Demonstration am 31.05.2017." Berliner Bündnis gegen Abschiebungen nach Afghanistan.

Berliner Morgenpost. 2015. "Tempelhof: So leben die Flüchtlinge im FlughafenHangar." Berliner Morgenpost, 25 November. https://www.morgenpost.de/berlin/ 
article206719997/Tempelhof-So-leben-die-Fluechtlinge-im-Flughafen-Hangar. html.

—. 2017. "Hunderte demonstrieren gegen Abschiebungen nach Afghanistan." Berliner Morgenpost Online, 11 February. https://www.morgenpost.de/berlin/article209576987/Hunderte-demonstrieren-gegen-Abschiebung-nach-Afghanistan. html.

Borkowsky, Luca, ed. 2019. Afghan Memories. Berlin.

Bundesinnenministerium. 2016. "Gemeinsame Erklärung zur Migration zwischen Deutschland und Afghanistan geschlossen.” 2 October. https://www.bmi.bund. de/SharedDocs/pressemitteilungen/DE/2016/og/gemeinsame-erklaerungmigration-deutschland-und-afghanistan.html.

BZ Online. 2017. "Protest von Hunderten afghanischen Flüchtlingen in Berlin gegen Abschiebungen." BZ Online, 21 September. https://www.bz-berlin.de/berlin/protestvon-hunderten-afghanischen-fluechtlingen-in-berlin-gegen-abschiebungen.

Daxner, Michael, and Silvia-Lucretia Nicola. 2017. Mapping of and Report on the Afghan Diaspora in Germany. Bremen: Centre for International Migration and Development.

Deutscher Bundestag. 2016. "Antwort der Bundesregierung auf die Kleine Anfrage der Abgeordneten Ulla Jelpke, Frank Tempel, Jan Korte, Weiterer Abgeordneter und der Fraktion DIE LINKE. Drucksache 18/100o6." http://dip21.bundestag.de/ $\operatorname{dip} 21 / \mathrm{btd} / 18 / 103 / 1810336 . p d f$.

Die Bundesregierung. 2015. "Zu geordnetem Verfahren zurückkehren." 28 October. https://www.bundesregierung.de/Content/DE/Artikel/2015/10/2015-10-28-demaizière-statements.html.

Die Welt Online. 2016. "1500 demonstrieren gegen Abschiebungen nach Afghanistan.” Die Welt Online, 10 December. https://www.welt.de/regionales/berlin/ article160177549/1500-demonstrieren-gegen-Abschiebungen-nach-Afghanistan. html.

—. 2017. "Berlin macht bei Abschiebungen nach Afghanistan nicht mit." Die Welt Online, 22 February. https://www.welt.de/regionales/berlin/article162288657/ Berlin-macht-bei-Abschiebungen-nach-Afghanistan-nicht-mit.html.

EEAS. 2016. "Joint Way Forward on Migration Issues between Afghanistan and the EU.” European Union External Action. 2 October. https://eeas.europa.eu/ sites/eeas/files/eu_afghanistan_joint_way_forward_on_migration_issues.pdf.

Ehrich, Issio. 2016. "Afghanen fürchten Abschiebungen. 'Lieber sterbe Ich in Deutschland.” $n$-tv, 11 December. https://www.n-tv.de/politik/Lieber-sterbeich-in-Deutschland-article19297961.html?fbclid=IwAR3W_OaVfwjR5FpzzC8MPJMKqLofUWCoLr7ctbRKCMUS5TQAN8Byh-KkR-4s.

Fischer, Carolin. 2019. "Afghanische Migration nach Deutschland: Geschichte und aktuelle Debatten.” BpB Länderprofile, 2 April. https://www.bpb.de/ 
gesellschaft/migration/laenderprofile/288717/afghanische-migration-nachdeutschland\#footnode11-11.

Gerner, Martin. 2016. "Afghanischen Flüchtlingen droht die Abschiebung." Deutschlandfunk, 19 November. https://www.deutschlandfunk.de/rueckfuehrung-afghanischen-fluechtlingen-droht-die.1773.de.html?dram:article id $=371817$.

Grande, Edgar. 2018. "Zivilgesellschaft, politischer Konflikt und soziale Bewegungen." Forschungsjournal Soziale Bewegungen 31 (1-2): 52-59.

Gürgen, Malene. 2017. "Afghanen gehen auf die Straße." Die Tageszeitung, 11 February. https://taz.de/Protest-gegen-Abschiebungen-in-Berlin/!5379453/.

Hamann, Ulrike, and Serhat Karakayali. 2017. "Practicing Willkommenskultur: Migration and Solidarity in Germany." Intersections 2 (4): 69-86.

Hamburger Abendblatt. 2017. "1500 Menschen demonstrieren in der City gegen Abschiebungen." Hamburger Abendblatt, 11 February. https://www.abendblatt. de/hamburg/article209575741/Demo-gegen-Abschiebungen-startet-an-derElbphilharmonie.html.

Handelsblatt. 2017. "Protest wegen Sammelabschiebung nach Afghanistan." Frankfurt Allgemeine Zeitung, 23 January. https://www.handelsblatt.com/politik/ deutschland/frankfurter-flughafen-protest-wegen-sammelabschiebung-nachafghanistan/19294392.html?ticket=ST-227016-bc6VsKg53334DRZaTls9-ap1.

Hillebrand, Fabian. 2017. "Protest für ein 'abschiebefreies Afghanistan.” Neues Deutschland, 8 June. Berlin. https://www.neues-deutschland.de/artikel/1053452. protest-fuer-ein-abschiebefreies-afghanistan.html.

Jakob, Christian. 2016. Die Bleibenden. Wie Flüchtlinge Deutschland seit 2o Jahren verändern. Berlin: Ch. Links Verlag.

Jasper, James M. 2014. "Constructing Indignation: Anger Dynamics in Protest Movements." Emotion Review 6 (3): 208-213.

Kaminski, Simon. 2017. "Wieder Abschiebungen nach Afghanistan - Proteste in München." Augsburger Allgemeine, 22 February. https://www.augsburgerallgemeine.de/bayern/Wieder-Abschiebungen-nach-Afghanistan-Proteste-inMuenchen-id40634921.html.

KuB. 2016. "Afghanistan Ist alles andere als sicher." Kontakt- und Beratungsstelle für Flüchtlinge und Migrant_innen. https://kub-berlin.org/images/documents/ Newsletter/KuB-Newsletter-2016_4.pdf.

Laubenthal, Barbara. 2019. "Refugees Welcome? Reforms of German Asylum Policies Between 2013 and 2017 and Germany's Transformation into an Immigration Country." German Politics, no. Online First: 1-14. https://doi.org/10.1080/og64 4008.2018.1561872.

Lochner, Susanne. 2018. "Integrationskurse als Motor für gesellschaftlichen Zusammenhalt?" BpB Kurzdossier, ${ }_{5}$ February. http://www.bpb.de/gesellschaft/ 
migration/kurzdossiers/264011/integrationskurse-als-motor-fuer-gesellschaftlichen-zusammenhalt.

Mediendienst Integration. 2018. "Flüchtlingsdebatte. Die wichtigsten Begriffe für den Journalisten-Alltag." March. https://mediendienst-integration.de/fileadmin/ Dateien/Informationspapier_Begriffe_Asyldebatte.pdf.

Newsgroup Afghanistan. 2017. "Afghanen in Deutschland: 'Als ob wir in den Tod geschickt werden.” dis:orient, 13 February. https://www.disorient.de/blog/ afghanen-deutschland-als-ob-wir-den-tod-geschickt-werden.

Nicholls, Walter J., and Justus Uitermark. 2016. Cities and Social Movements: Immigrant Rights Activism in the United States, France, and the Netherlands, 1970-2015. New York: John Wiley \& Sons.

Pichl, Maximilian. 2016. "Die Asylpakete I und II: Der politische und rechtliche Kampf um die Asylrechtsverschärfungen.” In Der lange Sommer der Migration. Grenzregime III, edited by Sabine Hess, Bernd Kasparek, Stefanie Kron, Mathias Rodatz, Maria Schwertl, and Simon Sontowski, 163-175. Berlin: Assoziation A. Pieper, Tobias. 2008. Die Gegenwart der Lager. Zur Mikrophysik der Herrschaft in der deutschen Flüchtlingspolitik. Münster: Westfälisches Dampfboot.

Pro Asyl. 2018. "Lange gefordert, endlich da: Lagebericht zu Afghanistan." 4June. https:// www.proasyl.de/news/lange-gefordert-endlich-da-lagebericht-zu-afghanistan/.

Rahimi, Mortaza. 2018. "Afghanen auf unsicherem Terrain." KulturTür, no. 1: 24-27. http://www.kulturtuer.net/wp-content/uploads/2018/04/Kultur-Tuer_Ausgabe6-WEB-3.pdf.

Rasuoli, Somayeh, and Mahdi Yaghobi. 2017. "Zurück an die Kriegsfront - Die Abschiebung afghanischer Flüchtlinge." KulturTür, no. 2/2017: 20-25. http://www. kulturtuer.net/wp-content/uploads/2018/o2/Kultur-Tuer_Ausgabe_02-min.pdf.

Rea, Andrea, Marco Martiniello, Alessandro Mazzola, and Bart Meuleman, eds. 2019. The Refugee Reception Crisis in Europe: Polarized Opinions and Mobilizations. Brussels: Éditions de l'Université de Bruxelles.

Reuters. 2016. "Verhandlungen zu Abschiebeabkommen mit Afghanistan kommen voran." Reuters, 15 September. https://de.reuters.com/article/ deutschland-fl-chtlinge-afghanistan-idDEKCNıLız.

Rezaie, Ali Ahmad. 2018a. "Brücke zwischen den Kulturen. Der Verein Yaar hilft afghanischen Geflüchteten in Berlin.” KulturTür, no. 4/2018: 22-25.

- . 2018b. "Newsgroup Afghanistan. Tribüne für Geflüchtete in Berlin." KulturTür, no. 1/2018. 42-45.

Romeo, Antonella. 2001. "Im Exil rückt das tyrannisierte Volk zusammen." Zeit Online, 4 October. https://www.zeit.de/2001/41/Im_Exil_rueckt_das_tyrannisierte_Volk_zusammen.

Ruttig, Thomas. 2017. "Afghan Exodus: Afghan Asylum Seekers in Europe (3) - Case Study Germany.” Afghanistan Analysts Network, 17 February. https://www. 
afghanistan-analysts.org/afghan-exodus-afghan-asylum-seekers-in-europe3-case-study-germany/.

Schleiermacher, Uta. 2017. “Liegt Berlin in 'Bleibistan'?” Die Tageszeitung, 31 May. Spiegel Online. 2018. "69 abgelehnte Asylbewerber nach Afghanistan abgeschoben." Spiegel Online, 4July. http://www.spiegel.de/politik/ausland/afghanistan-ersteabschiebung-seit-neuem-lagebericht-69-asylbewerber-betroffen-a-1216644.html.

Starzmann, Paul. 2017. "Warum SPD-Landesregierungen nicht nach Afghanistan abschieben wollen." Vorwärts, 23 February. https://www.vorwaerts.de/artikel/ spd-landesregierungen-afghanistan-abschieben-wollen.

Steinhilper, Elias. 2018. "Mobilizing in Transnational Contentious Spaces: Linking Relations, Emotions and Space in Migrant Activism.” Social Movement Studies 17 (5): 574-591. https://doi.org/10.1080/14742837.2018.1499510.

Täubig, Vicki. 2009. Totale Institution Asyl: Empirische Befunde zu alltäglichen Lebensführungen in der organisierten Desintegration. Weinheim: Juventa.

Taylor, Verta, and Alison Dahl Crossley. 2013. "Abeyance.” In The Wiley-Blackwell Encyclopedia of Social and Political Movements, edited by David A. Snow, Donatella della Porta, Bert Klandermans, and Doug McAdam, 1-2. Hoboken: Wiley-Blackwell. https://doi.org/10.1002/9781405198431.wbespmoo1.

UN OHCHR. 2016. "Afghanistan. Annual Report 2015. Protection of Civilians in Armed Conflict." UN Office of the High Commissioner for Human Rights. https://www.ohchr.org/Documents/Countries/AF/ProtectionCiviliansAnnualReport2015.pdf.

Weissenborn, Bodo. 2016. "Sicher ist: Afghanistan ist es nicht." dis:orient, 23 November. https://www.disorient.de/blog/sicher-ist-afghanistan-ist-es-nicht.

Zeit Online. 2015. "Merkel warnt Afghanen vor Flucht nach Deutschland." Zeit Online. 2 December. https://www.zeit.de/politik/ausland/2015-12/ merkel-ghani-afghanistan-fluchtursachen.

—. 2018. "Seehofer nennt Suizid von abgeschobenem Afghanen zutiefst bedauerlich." Zeit Online, 11 July. https:/www.zeit.de/politik/ausland/2018-07/ fluechtlinge-horst-seehofer-kabul-abschiebung-selbstmord.

Zepeda-Millán, Chris. 2014. "Perceptions of Threat, Demographic Diversity, and the Framing of Illegality: Explaining (Non)Participation in New York's 2006 Immigrant Protests." Political Research Quarterly 67 (4): 880-888.

- 2017. Latino Mass Mobilizations: Immigration, Racialization, and Activism. Cambridge: Cambridge University Press. 
